\title{
Stock Valuation in Pharmaceutical Sub- Sector Companies using the Discounted Cash Flow and Relative Valuation Methods in the 2013-2020 Period
}

\author{
Afna Dalilah $^{\# 1}$, Riko Hendrawan ${ }^{* 2}$ \\ \#,* Faculty of Economics and Business, Telkom University \\ Jl. Gegerkalong Hilir No. 47, Bandung 40152
}

\begin{abstract}
This research aims at calculating the fair value of shares of pharmaceutical companies listed on the Indonesia Stock Exchange (IDX). The data used in this research is historical data from the 2013-2020 financial statements, which are used as the basis for projections in 2021-2025. The method used in this research is Discounted Cash Flow (DCF) method with Free Cash Flow to the Firm (FCFF) approach and Relative Valuation method with Price to Earning Ratio (PER) and Price to Book Value (PBV) approaches in three scenarios. The three scenarios used are the optimistic scenario (condition above industry growth), the moderate scenario (the most likely condition for the company), and the pessimistic scenario (the average condition of the industry). The results of the research showed that by using the DCF-FCFF method, KAEF and PYFA stocks experienced overvalued conditions in all scenarios. Meanwhile, KLBF and DVLA stocks were undervalued in all scenarios. Then, from the calculation of the Relative Valuation method, each company was still within the industry range in all scenarios. Overall, KAEF stocks were overvalued by $57.817 \%$, KLBF stocks were undervalued by $7.879 \%$, DVLA stocks were undervalued by $370.865 \%$, and PYFA stocks were overvalued by $16.662 \%$ both in DCF method and in Relative Valuation method.
\end{abstract}

Keywords - Valuation, Intrinsic Value, Discounted Cash Flow, Relative Valuation, Pharmaceutical SubSector

\section{INTRODUCTION}

The pharmaceutical industry in Indonesia is one of the industries that has a rapid development with a market that continues to expand and develop, and is the largest pharmaceutical industry market in the ASEAN region ${ }^{[1]}$. The Food and Drug Supervisory Agency (BPOM) in 2005 stated that pharmaceutical growth in Indonesia was averaged $14.10 \%$ per year, which was higher than the national economic growth rate of $5 \%-6 \%$ per year. However, according to Airlangga Hartato, which is Minister of Industry of the Republic of Indonesia, the pharmaceutical industry still has problems with the production of raw materials, where nearly $90 \%$ of raw materials are imported ${ }^{[12]}$.

The European economic conditions had a significant impact on Indonesia, causing a decline in the volume and value of exports recorded in 2012, namely a decrease of $6.62 \%$ of total exports in 2011 and the foreign trade balance experienced a deficit of 1.66 billion $^{[2]}$. Another impact is the depreciation of the Rupiah exchange rate, thus affecting the performance of the pharmaceutical industry sector, which almost $90 \%$ of its raw materials are imported. As the country with the fourth largest population in the world, the Indonesian people's need for medicines is very large. So that the first sector that should be the focus of the government is to continue to increase investment in the health sector, especially in the pharmaceutical industry. The data on stock price movements of KAEF, KLBF, DVLA, and PYFA which are pharmaceutical issuers in Indonesia in the 20132020 period are presented in Figure 1.

The stock price of the pharmaceutical issuer was still below the IHSG, which means that the pharmaceutical industry was still below the market average. Quoting from Damodaran ${ }^{[3]}$ in 2006, that a good investor does not pay more for an asset than its value because the price paid for an asset must reflect the cash flows that are expected to be generated by a company. Meanwhile, debt financing through financial report is not becoming 
DOI: $\underline{10.51386 / 25815946 / \mathrm{ijsms}-\mathrm{v} 4 \mathrm{i} 4 \mathrm{p} 116}$

investor's consideration in making stock purchase decisions, because there is no difference in the value of companies that have neither high nor low debt financing ${ }^{[13]}$. When viewed from the results of the comparison of the CAGR in the pharmaceutical industry from 2013 to 2020 , which was $7.82 \%$ and the IHSG at $1.53 \%$, it showed that the pharmaceutical industry is a promising industry.

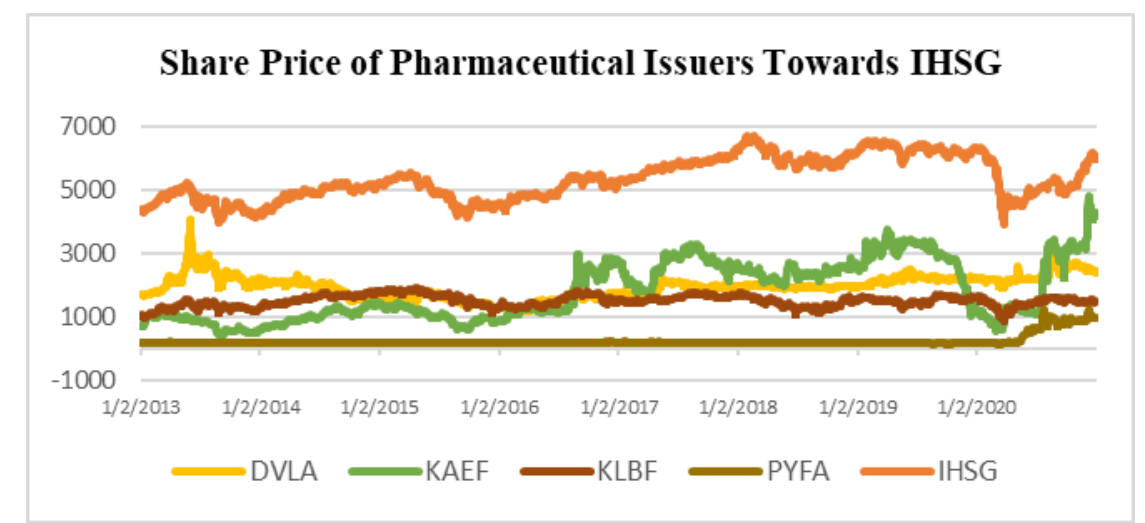

Fig 1. Stock Price Movement of Pharmaceutical Issuers towards IHSG from 2013 to 2020

Investing in stocks is an investment that is classified as high risk and high return, which is the opportunity to earn very large profits but if it is not managed properly then it has the possibility of large losses as well. Therefore, it is very important for investors to conduct stock assessments or stock valuations to minimize risk ${ }^{[11]}$. Figure 2 below shows the data and analysis of fluctuations in the value of risk and return of pharmaceutical issuers based on data from the IDX in the 2013-2020 period.

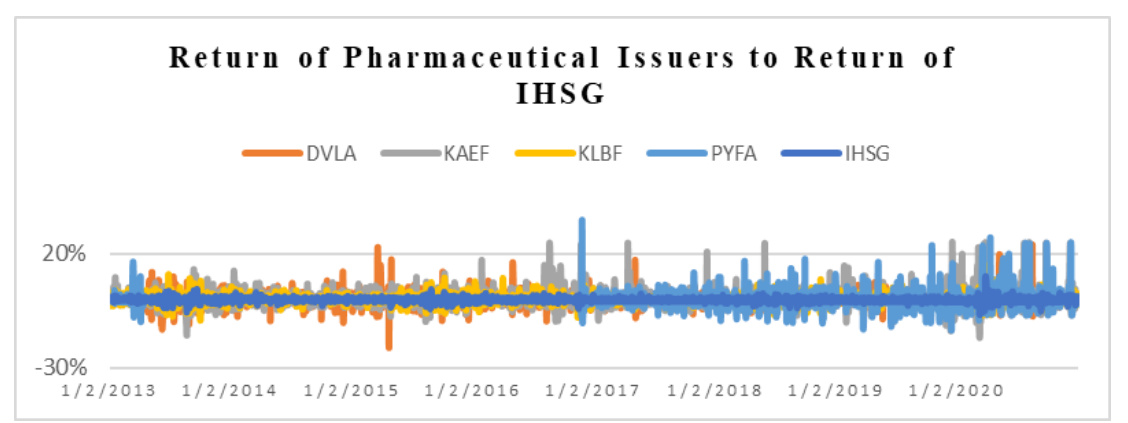

Fig 2. Return Rate of Pharmaceutical Issuers to the Return Rate of IHSG from 2013 to 2020

Fluctuations in stock returns or stock volatility indicate the risk of the stock itself, if it has high volatility, investors will speculate that they will get large profits in a short period of time, but in addition to large profits, high volatility will also result in large losses ${ }^{[10]}$.

The stock valuation method can be used to avoid losses from stock risk and assist in forecasting future volatility. According to Yulfita ${ }^{[15]}$ in 2013 , stock valuation is a process of determining the actual and reasonable price for a stock, which produces information in the form of intrinsic value which will be compared with the stock market price so that it can determine the buying or selling position of a company's stock. The true value or intrinsic value of a company can be related to its financial characteristics, such as its growth prospects, risk profile, and cash flow. If there is a deviation from the fair value of the stock, it indicates that the stock is undervalued or overvalued $^{[3]}$. The intrinsic value obtained from the calculation results can be compared with the market price, so that investors can determine the position of buying or selling a stock.

Based on the phenomenon and description in the aforementioned background, this research was conducted and entitled "Stock Valuation in Pharmaceutical Sub-Sector Companies using the Discounted Cash Flow and Relative Valuation Methods in the 2013-2020 Period". 
DOI: $\underline{10.51386 / 25815946 / i j s m s-v 4 i 4 p 116}$

Volume: 4 Issue: 4

July to August 2021

https://www.ijjsmsjournal.org

\section{LITERATURE REVIEW}

This research used several previous studies as a reference to determine the calculation method and how to do the calculations, as well as for conducting the evaluation.

Neaxie \& Hendrawan (2018) conducted research on the valuation of shares in telecommunications companies on the Indonesia Stock Exchange using the discounted cash flow (DCF) and relative valuation methods. The historical data used is the 2006-2016 financial statements for the 2017-2020 projection. The results of the research using the DCF method showed that the intrinsic value of TLKM and EXCL was undervalued and ISAT was overvalued in the optimistic scenario. In the moderate scenario, the intrinsic value of TLKM was undervalued, and ISAT and EXCL were overvalued. In the pessimistic scenario, the intrinsic value of TLKM, ISAT, and EXCL were overvalued. When using the PER approach, the intrinsic value of TLKM and EXCL was undervalued, and ISAT was overvalued. In the multiple PBV and EBITDA approach, the intrinsic value of TLKM was overvalued, and ISAT and EXCL were undervalued ${ }^{[9]}$.

Ivanovska et al. (2014) conducted a research to determine the intrinsic value of shares on the Macedonian Stock Exchange using the DFCF valuation model. The use of DFCF for corporate valuation evaluated the value of all investment opportunities of the company in comparison to the available cash flows that can be directed to both shareholders and creditors. The result showed that the intrinsic value calculated using DFCF had a result that was close to its fundamental value or market average value ${ }^{[6]}$.

Hendrawan et al. (2020) conducted a research entitled Stock Valuation of Cement Companies Listed on the Indonesia Stock Exchange using the DCF-FCFF Method and Relative Valuation Method, in which historical data used are financial statements for 2013-2017 to make projections for 2018-2022. The results showed that the fair value of INTP was overvalued in all scenarios, and SMCB and SMBR were overvalued in the pessimistic scenario but undervalued in the moderate and optimistic scenario. In calculating PER and PBV, all scenarios recommend selling INTP shares and buying SMCB and SMBR shares ${ }^{[5]}$.

Yulfita (2013) conducted a research to estimate stock prices in the manufacturing sector in the 2009-2011 period using the DDM and DCF methods. The results showed that there was no price difference between the fair price per share and the one issued by each sector ${ }^{[15]}$.

Suryanto (2016) calculated the intrinsic value of shares and chooses any stocks that were suitable for investors to invest in LQ45 index stocks in February 2016 using the PER method. In conclusion, 10 companies out of 13 companies, namely AKRA, ASII, BBCA, BBNI, BBRI, JSMR, LKPR, MPPA, UNTR, and UNVR were undervalued. Meanwhile, ADRO, BMRI, and SCMA were in overvalued condition ${ }^{[11]}$.

Natalia et al. (2019) conducted a research to analyze the fair value of shares in companies that were members of the consumer goods sector on the IDX in 2013 - 2017 using the DDM method and relative valuation. The results showed that the average of the seven company shares in the consumer goods sector in 2013-2017 was undervalued $^{[8]}$.

Jeletic (2012) defined and examined the approach to using cash flow for company valuation in 2008-2011. The perspective is using cash flow as a clear assessment tool. The method used is DCF with FCFF and FCFE approaches. It was found that the market in Croatia was still developing, so financial reports could become more accurate and trigger opportunities from more advanced models. Cash flow and other advanced models could be applied in emerging markets such as Croatia ${ }^{[7]}$.

Utamaningsih (2020) analyzed stock prices of state-owned construction companies when the stock market in Indonesia was bullish (stock prices tend to strengthen). The historical data used is from 2015 to 2018 to make projections for the next 5 years using the WACC, Terminal Value, and PBV methods. The results showed that the company had high debt and selling costs, resulting in a decreased capital structure. The decline affected investors' assessment of the increase in stock prices ${ }^{[14]}$.

\section{METHOD}


DOI: $\underline{10.51386 / 25815946 / \mathrm{ijsms}-\mathrm{v} 4 \mathrm{i} 4 \mathrm{p} 116}$

Volume: 4 Issue: 4

July to August 2021

https://www.ijjsmsjournal.org

The population in this research is all shares of public companies in the pharmaceutical sub-sector companies listed on the Indonesia Stock Exchange (IDX). The sample selection in this research is using purposive sampling technique by setting the sample criteria as follows:

1. These companies are listed on the IDX in the pharmaceutical sector.

2. These pharmaceutical companies did not have negative EBIT during the 2013-2020 period.

3. These pharmaceutical companies had a positive average stock return during the 2013-2020 period.

The list of companies that meet these criteria are four companies listed as pharmaceutical companies, namely PT. Kalbe Farma Tbk (KLBF), PT. Kimia Farma Tbk (KAEF), PT. Darya-Varia Laboratoria Tbk (DVLA), and PT. Pyridam Farma Tbk (PYFA).

The data collection in this research is in the form of collecting company financial statements for the 20132020 period which can be obtained through the IDX website (www.idx.co.id) and the official website of each company. The movement of the company's stock price and IHSG as well as information related to market conditions are taken from financial websites (www.idnfinancials.com and www.finance.yahoo.com). Then, the historical data were averaged and the percentage were calculated as reference data for projections for the next five years, namely in the 2021 to 2025 period. The data taken were in the form of sales data (revenue), operating expenses, EBIT, depreciation costs and amortization, capital expenditure, tax expense, and net working capital.

\section{RESULTS}

\section{A. PT. Kimia Farma Tbk. (KAEF)}

Prior to stock valuation, the first step was to collect historical data from the company's financial statements for the 2013-2020 period, where the average calculation was carried out in the form of a percentage to be used as a reference for the 2021-2025 projection. The historical data of KAEF shares are presented in Table 1, the results of the company's WACC calculations are presented in Table 2, the company's FCFF projections for 2021-2025 are presented in Table 3, and the results of the calculation of stock valuations with a total outstanding share price of 5,554,000,000 shares are presented in Table 4.

Table 1. Historical Data of KAEF Financial Report in 2013-2020 (in Million Rupiah)

\begin{tabular}{|c|c|c|c|c|c|c|c|c|c|}
\hline & 2013 & 2014 & 2015 & 2016 & 2017 & 2018 & 2019 & 2020 & Average \\
\hline Revenue & $4,348,074$ & $4,521,024$ & $4,860,371$ & $5,811,503$ & $6,127,479$ & $7,454,115$ & $9,400,535$ & $10,006,173$ & \multirow{2}{*}{$13.39 \%$} \\
\hline Growth & $16.438 \%$ & $3.978 \%$ & $7.506 \%$ & $19.569 \%$ & $5.437 \%$ & $21.651 \%$ & $26.112 \%$ & $6.443 \%$ & \\
\hline $\begin{array}{l}\text { Total Op. } \\
\quad \text { Exp }\end{array}$ & $4,054,048$ & $4,178,544$ & $4,486,042$ & $5,368,679$ & $5,591,818$ & $6,689,097$ & $8,898,880$ & $9,353,149$ & $92.43 \%$ \\
\hline EBIT & 294,026 & 342,481 & 374,329 & 442,824 & 535,661 & 765,017 & 501,656 & 653,024 & $7.57 \%$ \\
\hline Depreciation & 30,963 & 39,333 & 48,374 & 52,554 & 64,286 & 102,784 & 67,979 & 241,946 & $1.13 \%$ \\
\hline Capex & 89,030 & 102,413 & 146,205 & 370,185 & 751,823 & $1,010,690$ & 774,407 & 544,486 & $6.65 \%$ \\
\hline WC & 672,077 & 614,056 & 553,622 & 564,292 & 305,396 & $(146,274)$ & $(861,998)$ & $(1,156,052)$ & \\
\hline$\Delta \mathrm{WC}$ & 113,504 & $(58,021)$ & $(60,434)$ & 10,670 & $(258,896)$ & $(451,670)$ & $(715,724)$ & $(294,054)$ & $-29.13 \%$ \\
\hline
\end{tabular}

Table 2. KAEF WACC Calculation

\begin{tabular}{|c|c|}
\hline Cost of Equity $(\mathrm{ke})$ & $6.026 \%$ \\
\hline Cost of Debt $(\mathrm{kd})$ after tax & $13.228 \%$ \\
\hline Capital Structure & $\mathrm{We}=67.757 \% ; \mathrm{Wd}=32.243 \%$ \\
\hline WACC & $\mathbf{8 . 3 4 8 \%}$ \\
\hline
\end{tabular}

Table 3. FCFF Projection of KAEF for 2021-2025

\begin{tabular}{|c|c|c|c|c|c|c|c|}
\hline Scenario & $\mathbf{2 0 2 1}$ & $\mathbf{2 0 2 2}$ & $\mathbf{2 0 2 3}$ & $\mathbf{2 0 2 4}$ & $\mathbf{T V}$ & $\begin{array}{c}\text { Enterprise } \\
\text { Value }\end{array}$ & $\begin{array}{c}\text { Equity } \\
\text { Value }\end{array}$ \\
\hline Optimistic, g: $17.343 \%$ & 306,432 & 359,576 & 421,937 & 495,113 & $18,266,120$ & $14,534,428$ & $12,403,155$ \\
\hline Moderate, g: 13.392\% & 296,113 & 335,767 & 380,732 & 431,718 & $15,927,310$ & $12,729,134$ & $10,597,861$ \\
\hline Pessimistic, g: $5.489 \%$ & 275,476 & 290,597 & 306,548 & 323,374 & $11,930,188$ & $9,634,265$ & $7,502,992$ \\
\hline
\end{tabular}


DOI: $\underline{10.51386 / 25815946 / \mathrm{ijsms}-\mathrm{v} 4 \mathrm{i} 4 \mathrm{p} 116}$

Table 4. KAEF Stock Valuation Results

\begin{tabular}{|c|c|c|c|c|c|}
\hline \multicolumn{6}{|c|}{ DCF-FCFF } \\
\hline Scenario & $\begin{array}{c}\text { Intrinsic } \\
\text { Value }\end{array}$ & \multicolumn{3}{|c|}{ Share Price in Market (4 January 2021) } & Condition \\
\hline Optimistic & 2,233 & \multirow{3}{*}{\multicolumn{3}{|c|}{4,340}} & Overvalued \\
\hline Moderate & 1,908 & & & & Overvalued \\
\hline Pessimistic & 1,351 & & & & Overvalued \\
\hline \multicolumn{6}{|c|}{ RV-PER } \\
\hline Scenario & PER & $\begin{array}{c}\text { Min (IDX } \\
\text { Annual 2020) }\end{array}$ & $\begin{array}{l}\text { Average (IDX } \\
\text { Annual 2020) }\end{array}$ & $\begin{array}{c}\text { Max (IDX } \\
\text { Annual 2020) }\end{array}$ & $\begin{array}{c}\text { In Range? } \\
\text { (Yes/No) }\end{array}$ \\
\hline Optimistic & 22.60 & \multirow{3}{*}{ (496) } & \multirow{3}{*}{43.93} & \multirow{3}{*}{476} & Yes \\
\hline Moderate & 19.99 & & & & Yes \\
\hline Pessimistic & 15.21 & & & & Yes \\
\hline \multicolumn{6}{|c|}{ RV-PBV } \\
\hline Scenario & PBV & $\begin{array}{c}\text { Min (IDX } \\
\text { Annual 2020) }\end{array}$ & $\begin{array}{l}\text { Average (IDX } \\
\text { Annual 2020) }\end{array}$ & $\begin{array}{c}\text { Max (IDX } \\
\text { Annual 2020) }\end{array}$ & $\begin{array}{c}\text { In Range? } \\
\text { (Yes/No) }\end{array}$ \\
\hline Optimistic & 1.75 & \multirow{3}{*}{0.13} & \multirow{3}{*}{4.932} & \multirow{3}{*}{25.7} & Yes \\
\hline Moderate & 1.49 & & & & Yes \\
\hline Pessimistic & 1.06 & & & & Yes \\
\hline
\end{tabular}

\section{B. PT Kalbe Farma Tbk. (KLBF)}

In conducting stock valuation, the first step that needs to be done was to analyze the historical data of the company's financial statements for 2013-2020 which was then presented as a basis for projections for 20212025. Historical data on KLBF shares is presented in Table 5, the results of the company's WACC calculations are presented in Table 6, the company's FCFF projections for 2021-2025 are presented in Table 7, and the results of the calculation of stock valuation with a total outstanding share price of 46,875,122.110 shares are presented in Table 8.

Table 5. Historical Data of KLBF Financial Report in 2013-2020 (in Million Rupiah)

\begin{tabular}{|ccccccccc|c|}
\hline & $\mathbf{2 0 1 3}$ & $\mathbf{2 0 1 4}$ & $\mathbf{2 0 1 5}$ & $\mathbf{2 0 1 6}$ & $\mathbf{2 0 1 7}$ & $\mathbf{2 0 1 8}$ & $\mathbf{2 0 1 9}$ & $\mathbf{2 0 2 0}$ & Average \\
\hline Revenue & $16,002,131$ & $17,368,533$ & $17,887,464$ & $19,374,231$ & $20,182,120$ & $21,074,306$ & $22,633,476$ & $23,112,655$ & \multirow{2}{*}{$6.91 \%$} \\
Growth & $17.349 \%$ & $8.539 \%$ & $2.988 \%$ & $8.312 \%$ & $4.170 \%$ & $4.421 \%$ & $7.398 \%$ & $2.117 \%$ \\
Total Op. & & & & & & & & \\
Exp & $13,473,123$ & $14,613,554$ & $15,223,342$ & $16,383,119$ & $17,023,150$ & $17,861,281$ & $19,333,512$ & $19,568,700$ & $84.65 \%$ \\
EBIT & $2,529,008$ & $2,754,978$ & $2,664,123$ & $2,991,112$ & $3,158,970$ & $3,213,025$ & $3,299,964$ & $3,543,955$ \\
Depreciation & 255,399 & 308,234 & 351,148 & 397,069 & 403,190 & 426,008 & 462,704 & 597,307 & $2.00 \%$ \\
Capex & 993,929 & 750,706 & 903,743 & $1,039,051$ & $1,163,835$ & $1,307,327$ & $1,733,323$ & 926,997 & $5.57 \%$ \\
WC & $3,430,360$ & $3,840,276$ & $3,665,821$ & $4,373,292$ & $5,036,523$ & $5,237,045$ & $5,624,414$ & $4,839,441$ & $1.53 \%$ \\
$\Delta$ WC & 739,636 & 409,916 & $(174,454)$ & 707,471 & 663,230 & 200,522 & 387,369 & $(784,973)$ & \\
\hline
\end{tabular}

Table 6. KLBF WACC Calculation

\begin{tabular}{|c|c|}
\hline Cost of Equity (ke) & $7.847 \%$ \\
\hline Cost of Debt $(\mathrm{kd})$ after $\operatorname{tax}$ & $7.168 \%$ \\
\hline Capital Structure & $\mathrm{We}=95.122 \% ; \mathrm{Wd}=4.878 \%$ \\
\hline WACC & $\mathbf{7 . 8 1 3 \%}$ \\
\hline
\end{tabular}


DOI: $\underline{10.51386 / 25815946 / \mathrm{ijsms}-\mathrm{v} 4 \mathrm{i} 4 \mathrm{p} 116}$

Table 7. FCFF Projection of KLBF for 2021-2025

\begin{tabular}{|c|c|c|c|c|c|c|c|}
\hline Scenario & $\mathbf{2 0 2 1}$ & $\mathbf{2 0 2 2}$ & $\mathbf{2 0 2 3}$ & $\mathbf{2 0 2 4}$ & TV & $\begin{array}{c}\text { Enterprise } \\
\text { Value }\end{array}$ & $\begin{array}{c}\text { Equity } \\
\text { Value }\end{array}$ \\
\hline Optimistic, g: $7.623 \%$ & $1,596,308$ & $1,717,994$ & $1,848,956$ & $1,989,901$ & $90,304,963$ & $72,744,153$ & $77,014,767$ \\
\hline Moderate, g: 6.912\% & $1,585,757$ & $1,695,359$ & $1,812,536$ & $1,937,812$ & $87,941,080$ & $70,897,701$ & $75,168,315$ \\
\hline Pessimistic, g: $5.489 \%$ & $1,564,656$ & $1,650,540$ & $1,741,138$ & $1,836,709$ & $83,352,841$ & $67,311,877$ & $71,582,491$ \\
\hline
\end{tabular}

Table 8. KLBF Stock Valuation Results

\begin{tabular}{|c|c|c|c|c|c|}
\hline \multicolumn{6}{|c|}{ DCF-FCFF } \\
\hline Scenario & $\begin{array}{l}\text { Intrinsic } \\
\text { Value }\end{array}$ & \multicolumn{3}{|c|}{ Share Price in Market (4 January 2021) } & Condition \\
\hline Optimistic & 1,643 & \multirow{3}{*}{\multicolumn{3}{|c|}{1,475}} & Undervalued \\
\hline Moderate & 1,604 & & & & Undervalued \\
\hline Pessimistic & 1,527 & & & & Undervalued \\
\hline \multicolumn{6}{|c|}{ RV-PER } \\
\hline Scenario & PER & $\begin{array}{c}\text { Min (IDX } \\
\text { Annual 2020) }\end{array}$ & $\begin{array}{c}\text { Average (IDX } \\
\text { Annual 2020) }\end{array}$ & $\begin{array}{c}\text { Max (IDX } \\
\text { Annual 2020) }\end{array}$ & $\begin{array}{c}\text { In Range? } \\
\text { (Yes/No) }\end{array}$ \\
\hline Optimistic & 29.73 & \multirow{3}{*}{$(496)$} & \multirow{3}{*}{43.93} & \multirow{3}{*}{476} & Yes \\
\hline Moderate & 29.21 & & & & Yes \\
\hline Pessimistic & 28.19 & & & & Yes \\
\hline \multicolumn{6}{|c|}{ RV-PBV } \\
\hline Scenario & PBV & $\begin{array}{c}\text { Min (IDX } \\
\text { Annual 2020) }\end{array}$ & $\begin{array}{l}\text { Average (IDX } \\
\text { Annual 2020) }\end{array}$ & $\begin{array}{c}\text { Max (IDX } \\
\text { Annual 2020) }\end{array}$ & $\begin{array}{c}\text { In Range? } \\
\text { (Yes/No) }\end{array}$ \\
\hline Optimistic & 4.21 & \multirow{3}{*}{0.13} & \multirow{3}{*}{4.932} & \multirow{3}{*}{25.7} & Yes \\
\hline Moderate & 4.11 & & & & Yes \\
\hline Pessimistic & 3.92 & & & & Yes \\
\hline
\end{tabular}

\section{PT. Darya-Varia Laboratoria Tbk. (DVLA)}

The first step before valuing shares was to analyze historical data on the company's financial statements for 2013-2020 to serve as the basis for projections for 2021-2025. Historical data on DVLA shares is presented in Table 9, the results of the company's WACC calculations are presented in Table 10, the company's FCFF projections for 2021-2025 are presented in Table 11, and the results of the calculation of stock valuation with a total outstanding share price of 1,120,000,000 shares are presented in Table 12.

Table 9. Historical Data of DVLA Financial Report in 2013-2020 (in Million Rupiah)

\begin{tabular}{|ccccccccc|c|}
\hline & $\mathbf{2 0 1 3}$ & $\mathbf{2 0 1 4}$ & $\mathbf{2 0 1 5}$ & $\mathbf{2 0 1 6}$ & $\mathbf{2 0 1 7}$ & $\mathbf{2 0 1 8}$ & $\mathbf{2 0 1 9}$ & $\mathbf{2 0 2 0}$ & Average \\
\hline Revenue & $1,101,684$ & $1,103,822$ & $1,306,098$ & $1,451,357$ & $1,575,647$ & $1,699,657$ & $1,813,020$ & $1,829,700$ & $6.87 \%$ \\
Growth & $1.315 \%$ & $0.194 \%$ & $18.325 \%$ & $11.122 \%$ & $8.564 \%$ & $7.870 \%$ & $6.670 \%$ & $0.920 \%$ & \\
Total Op. & 934,605 & $1,009,351$ & $1,179,360$ & $1,247,724$ & $1,355,681$ & $1,432,348$ & $1,516,397$ & $1,618,983$ & $86.87 \%$ \\
Exp & 167,079 & 94,471 & 126,738 & 203,632 & 219,966 & 267,310 & 296,624 & 210,716 & \\
EBIT & 32,411 & 35,753 & 38,694 & 40,370 & 46,795 & 49,748 & 53,931 & 59,564 & $3.01 \%$ \\
Depreciation & 54,936 & 60,593 & 32,201 & 195,963 & 38,397 & 45,488 & 58,955 & 62,807 & $4.78 \%$ \\
Capex & 391,286 & 442,803 & 353,820 & 354,089 & 324,303 & 527,546 & 549,554 & 649,102 & $2.27 \%$ \\
WC & 39,334 & 51,516 & $(88,982)$ & 269 & $(29,786)$ & 203,244 & 22,007 & 99,548 & \\
DWC & & & & & & & & & \\
\hline
\end{tabular}

Table 10. DVLA WACC Calculation

\begin{tabular}{|c|c|}
\hline Cost of Equity $(\mathrm{ke})$ & $6.518 \%$ \\
\hline Cost of Debt $(\mathrm{kd})$ after $\operatorname{tax}$ & $0.084 \%$ \\
\hline Capital Structure & $\mathrm{We}=94.986 \% ; \mathrm{Wd}=5.014 \%$ \\
\hline WACC & $\mathbf{6 . 1 9 6 \%}$ \\
\hline
\end{tabular}


DOI: $\underline{10.51386 / 25815946 / \mathrm{ijsms}-\mathrm{v} 4 \mathrm{i} 4 \mathrm{p} 116}$

Table 11. FCFF Projection of DVLA for 2021-2025 (in Million Rupiah)

\begin{tabular}{|c|c|c|c|c|c|c|c|}
\hline Scenario & $\mathbf{2 0 2 1}$ & $\mathbf{2 0 2 2}$ & $\mathbf{2 0 2 3}$ & $\mathbf{2 0 2 4}$ & TV & $\begin{array}{c}\text { Enterprise } \\
\text { Value }\end{array}$ & $\begin{array}{c}\text { Equity } \\
\text { Value }\end{array}$ \\
\hline Optimistic, g: $7.564 \%$ & 89,604 & 96,382 & 103,672 & 111,515 & $16,648,692$ & $13,434,533$ & $13,629,829$ \\
\hline Moderate, g: $6.873 \%$ & 89,028 & 95,146 & 101,685 & 108,673 & $16,224,530$ & $13,095,493$ & $13,290,790$ \\
\hline Pessimistic, g: $5.489 \%$ & 87,875 & 92,699 & 97,787 & 103,154 & $15,400,571$ & $12,436,785$ & $12,632,081$ \\
\hline
\end{tabular}

Table 12. DVLA Stock Valuation Results

\begin{tabular}{|c|c|c|c|c|c|}
\hline \multicolumn{6}{|c|}{ DCF-FCFF } \\
\hline Scenario & $\begin{array}{c}\text { Intrinsic } \\
\text { Value }\end{array}$ & \multicolumn{3}{|c|}{ Share Price in Market (4 January 2021) } & Condition \\
\hline Optimistic & 12,169 & \multirow{3}{*}{\multicolumn{3}{|c|}{2,500}} & Undervalued \\
\hline Moderate & 11,867 & & & & Undervalued \\
\hline Pessimistic & 11,279 & & & & Undervalued \\
\hline \multicolumn{6}{|c|}{ RV-PER } \\
\hline Scenario & PER & $\begin{array}{c}\text { Min (IDX } \\
\text { Annual 2020) }\end{array}$ & $\begin{array}{c}\text { Average (IDX } \\
\text { Annual 2020) }\end{array}$ & $\begin{array}{c}\text { Max (IDX } \\
\text { Annual 2020) }\end{array}$ & $\begin{array}{c}\text { In Range? } \\
\text { (Yes/No) }\end{array}$ \\
\hline Optimistic & 105.21 & \multirow{3}{*}{ (496) } & \multirow{3}{*}{43.93} & \multirow{3}{*}{476} & Yes \\
\hline Moderate & 103.26 & & & & Yes \\
\hline Pessimistic & 99.43 & & & & Yes \\
\hline \multicolumn{6}{|c|}{ RV-PBV } \\
\hline Scenario & PBV & $\begin{array}{c}\text { Min (IDX } \\
\text { Annual 2020) }\end{array}$ & $\begin{array}{c}\text { Average (IDX } \\
\text { Annual 2020) }\end{array}$ & $\begin{array}{c}\text { Max (IDX } \\
\text { Annual 2020) }\end{array}$ & $\begin{array}{c}\text { In Range? } \\
\text { (Yes/No) }\end{array}$ \\
\hline Optimistic & 10.28 & \multirow{3}{*}{0.13} & \multirow{3}{*}{4.932} & \multirow{3}{*}{25.7} & Yes \\
\hline Moderate & 10.02 & & & & Yes \\
\hline Pessimistic & 9.52 & & & & Yes \\
\hline
\end{tabular}

D. PT. Pyridam Farma Tbk. (PYFA)

Valuation of company shares using the DCF-FCFF method and relative valuation required historical data on the company's financial statements for 2013-2020 in the form of percentages, then used as the basis for projections for 2021-2025 period. PYFA stock historical data is presented in Table 13, the results of the company's WACC calculations are presented in Table 14, the company's FCFF projections for 2021-2025 are presented in Table 15, and the results of the calculation of stock valuation with a total outstanding share price of 46,875,122,110 shares are presented in Table 16.

Table 13. Historical Data of PYFA Financial Report in 2013-2020 (in Million Rupiah)

\begin{tabular}{|ccccccccc|c|}
\hline & $\mathbf{2 0 1 3}$ & $\mathbf{2 0 1 4}$ & $\mathbf{2 0 1 5}$ & $\mathbf{2 0 1 6}$ & $\mathbf{2 0 1 7}$ & $\mathbf{2 0 1 8}$ & $\mathbf{2 0 1 9}$ & $\mathbf{2 0 2 0}$ & Average \\
\hline Revenue & 192,556 & 222,302 & 217,844 & 216,952 & 223,002 & 250,446 & 247,115 & 277,398 & \multirow{2}{*}{$6.00 \%$} \\
Growth & $8.954 \%$ & $15.448 \%$ & $-2.006 \%$ & $-0.410 \%$ & $2.789 \%$ & $12.306 \%$ & $-1.330 \%$ & $12.255 \%$ & \\
Total Op. & 180,070 & 211,999 & 206,983 & 206,432 & 210,940 & 235,937 & 231,834 & 245,254 & $93.76 \%$ \\
Exp & & & & & & & & & \\
EBIT & 12,486 & 10,303 & 10,861 & 10,519 & 12,063 & 14,508 & 15,281 & 32,144 & \\
Depreciation & 7,999 & 10,849 & 10,015 & 9,181 & 8,616 & 7,301 & 7,446 & 8,282 & $3.83 \%$ \\
Capex & 13,081 & 3,515 & 1,996 & 2,578 & 3,304 & 20,444 & 3,235 & 7,695 & $3.03 \%$ \\
WC & 27,629 & 35,102 & 39,811 & 49,119 & 57,106 & 58,638 & 66,385 & 80,995 & $1.84 \%$ \\
$\Delta$ WC & $(14,753)$ & 7,473 & 4,709 & 9,308 & 7,987 & 1,532 & 7,747 & 14,610 & \\
\hline
\end{tabular}


Table 14. PYFA WACC Calculation

\begin{tabular}{|c|c|}
\hline Cost of Equity $(\mathrm{ke})$ & $7.428 \%$ \\
\hline Cost of Debt $(\mathrm{kd})$ after tax & $13.696 \%$ \\
\hline Capital Structure & $\mathrm{We}=91.819 \% ; \mathrm{Wd}=8.181 \%$ \\
\hline WACC & $\mathbf{7 . 9 4 1 \%}$ \\
\hline
\end{tabular}

Table 15. FCFF Projection of PYFA for 2021-2025 (in Million Rupiah)

\begin{tabular}{|c|c|c|c|c|c|c|c|}
\hline Scenario & $\mathbf{2 0 2 1}$ & $\mathbf{2 0 2 2}$ & $\mathbf{2 0 2 3}$ & $\mathbf{2 0 2 4}$ & $\mathbf{T V}$ & $\begin{array}{c}\text { Enterprise } \\
\text { Value }\end{array}$ & $\begin{array}{c}\text { Equity } \\
\text { Value }\end{array}$ \\
\hline Optimistic, g: $6.257 \%$ & 10,734 & 11,405 & 12,119 & 12,877 & 553,959 & 446,920 & 442,511 \\
\hline Moderate, g: $6.001 \%$ & 10,708 & 11,350 & 12,032 & 12,754 & 548,641 & 442,771 & 438,361 \\
\hline Pessimistic, g: $5.489 \%$ & 10,656 & 11,241 & 11,858 & 12,509 & 538,119 & 434,560 & 430,151 \\
\hline
\end{tabular}

Table 16. PYFA Stock Valuation Results

\begin{tabular}{|c|c|c|c|c|c|}
\hline \multicolumn{6}{|c|}{ DCF-FCFF } \\
\hline Scenario & $\begin{array}{c}\text { Intrinsic } \\
\text { Value }\end{array}$ & \multicolumn{3}{|c|}{ Share Price in Market (4 January 2021) } & Condition \\
\hline Optimistic & 827 & \multirow{3}{*}{\multicolumn{3}{|c|}{980}} & Overvalued \\
\hline Moderate & 819 & & & & Overvalued \\
\hline Pessimistic & 804 & & & & Overvalued \\
\hline \multicolumn{6}{|c|}{ RV-PER } \\
\hline Scenario & PER & $\begin{array}{c}\text { Min (IDX } \\
\text { Annual 2020) }\end{array}$ & $\begin{array}{c}\text { Average (IDX } \\
\text { Annual 2020) }\end{array}$ & $\begin{array}{c}\text { Max (IDX } \\
\text { Annual 2020) }\end{array}$ & $\begin{array}{c}\text { In Range? } \\
\text { (Yes/No) }\end{array}$ \\
\hline Optimistic & 39.24 & \multirow{3}{*}{ (496) } & \multirow{3}{*}{43.93} & \multirow{3}{*}{476} & Yes \\
\hline Moderate & 38.97 & & & & Yes \\
\hline Pessimistic & 38.42 & & & & Yes \\
\hline \multicolumn{6}{|c|}{ RV-PBV } \\
\hline Scenario & PBV & $\begin{array}{c}\text { Min (IDX } \\
\text { Annual 2020) }\end{array}$ & $\begin{array}{l}\text { Average (IDX } \\
\text { Annual 2020) } \\
\end{array}$ & $\begin{array}{c}\text { Max (IDX } \\
\text { Annual 2020) } \\
\end{array}$ & $\begin{array}{c}\text { In Range? } \\
\text { (Yes/No) }\end{array}$ \\
\hline Optimistic & 2.81 & \multirow{3}{*}{0.13} & \multirow{3}{*}{4.932} & \multirow{3}{*}{25.7} & Yes \\
\hline Moderate & 2.78 & & & & Yes \\
\hline Pessimistic & 2.73 & & & & Yes \\
\hline
\end{tabular}

\section{Discussion}

Based on historical data from financial statements from 2013 to 2020 for each company, this data were used as the basis for calculating FCFF and RV projections for the next 5 years, namely 2021 to 2025 using optimistic, moderate, and pessimistic scenarios. The results of these calculations can also be used as a reference for each company to be able to continue to grow and develop in order to survive and compete with similar companies, where it is known that the pharmaceutical industry is experiencing a fairly high increase and the demand from the Indonesian population is quite large.

KAEF shares were overvalued in all scenarios, where the stock price in the market on January 4, 2021 $(\mathrm{Rp} 4,340)$ was higher than the calculation of its intrinsic value. The stock price in the market was influenced by the sentiment of the COVID-19 vaccine, which was distributed freely by the government through KAEF, making KAEF's stock price on January 4, 2021 higher than in previous years. Then, when viewed from the results of the relative valuation calculation, the PER and PBV of KAEF were still in the industrial range and lower than the average PER and PBV of the industry. From the PER value in Table 4, it can also be inferred that KAEF shares had a longer time for investors to get their capital back. Overall, KAEF shares were overvalued by $57.817 \%$, so it can be recommended to investors for sale.

Meanwhile, KLBF shares were undervalued in all scenarios, where the stock price on the market on January 4, $2021(\mathrm{Rp} 1,475)$ was lower than the calculation of its intrinsic value. This is in line with the company's revenue growth projection, which was positive $7.623 \%$ in the optimistic scenario, positive $6.912 \%$ in the 
DOI: $\underline{10.51386 / 25815946 / i j s m s-v 4 i 4 p 116}$

Volume: 4 Issue: 4

July to August 2021

https://www.ijsmsjournal.org

moderate scenario, and positive $5.489 \%$ in the pessimistic scenario. Then, from the calculation of relative valuation, the PER and PBV of KLBF were still in the industrial range and lower than the average PER and PBV of the industry. The results of these calculations illustrate that KLBF's stock was relatively cheap compared to its competitors' stocks. Overall, KLBF shares were undervalued by $7.879 \%$, so KLBF shares can be recommended to investors to buy.

Furthermore, DVLA shares were undervalued in all scenarios, where the stock price in the market on January 4, 2021 (Rp2,500) was lower than its intrinsic value. However, when viewed from the results of the relative valuation calculation, DVLA shares were considered to have a higher share price than their competitors' shares. This is because the PER and PBV values were far above the industry average's PER and PBV. By having higher PER and PBV values, DVLA shares could provide investors with an overview of the long-term potential of the company's fundamental prospects. Overall, DVLA shares were undervalued by $370.865 \%$, so DVLA shares can be recommended to investors to buy. Meanwhile, for companies, if they want a low PER value, the company should be able to increase earnings per share from its shares.

Then, PYFA shares experienced overvalued conditions in all scenarios, where the stock price on the market on January 4, 2021 (Rp980) was higher than its intrinsic value. Like KAEF shares, PYFA shares were also affected by sentiment related to COVID-19, so the current stock price was higher than in previous years. Then, from the calculation of relative valuation, PYFA shares had PER and PBV values that were in the industrial range and lower than the average PER and PBV of the industry. This proves that by increasing the price of PYFA's shares in the market, the profits that will be obtained by investors per each share are higher. Therefore, overall, PYFA shares were overvalued by $16.662 \%$ and can be recommended to investors to sell to realize profits.

\section{CONCLUSION}

This research provides different valuation values with different growth assumptions. The four companies that are the object of this research, which are KAEF, KLBF, DVLA, and PYFA, provided fully valid DCF-FCFF calculation results and illustrate that the DCF-FCFF method is reliable and appropriate. This is in line with the results of research by Ivanovska et al. ${ }^{[6]}$ in 2014 , where DCF was a reliable and appropriate method to use in valuing shares, because this method will produce a fair value that is close to the stock price on the market and in accordance with the fundamental aspects of a company. Then, the results of the relative valuation calculation help validating the results of the DCF-FCFF calculation, where the PER and PBV values for each company are still in the industry range from IDX annual 2020. Recommendations that can be given to investors are buying KLBF and DVLA shares, and selling or immediately realizing profits from KAEF and PYFA shares.

\section{REFERENCES}

[1] Ariana, L., Maulana, I., Hartiningsih, Alamsyah, P., \& Prihadyanti, D. (2015). Technological Catch-up Industri Farmasi Indonesia. LIPI Press.

[2] BPS. (2013). Laporan Perekonomian Indonesia 2013. Jakarta: Badan Pusat Statistik.

[3] Damodaran, A. (2006). Damodaran on Valuation: Security Analysis for Investment and Corporate Finance, 2nd Edition (Second). Wiley Finance.

[4] DetikFinance. (2010. 20 Mei). Sri Mulyani: Krisis Eropa Ancaman Ekonomi RI di 2011. DetikFinance [online]. Tersedia: https://finance.detik.com/berita-ekonomi-bisnis/d-1360783/sri-mulyani-krisis-eropa-ancaman-ekonomi-ri-di-2011 [12 Februari 2021]

[5] Hendrawan, R., Rijikan, \& Tugiman, H. (2020). Stock Valuations in Cement Companies: Evidence from Indonesia Stock Exchange. The 2nd International Conference on Inclusive Business in the Changing World (ICIB 2019). May, 45-54. https://doi.org/10.5220/0008427400450054

[6] Ivanovska, N., Ivanovski, Z., \& Narasanov, Z. (2014). Fundamental Analysis and Discounted Free Cash Flow Valuation of Stocks At Macedonian Stock Exchange. UTMS Journal of Economics, 5(1), 11-24.

[7] Jeletic, T. (2012). Cash Flow and Company Valuation Analysis : Practical Approach To Ina Plc, the Biggest Croatian Oil Compa ny. International Journal of Arts \& Sciences, 5(7), 6934.

[8] Natalia, D., E.R, C. W., \& Yulita, I. K. (2019). Stock Valuation Analysis Using The Dividend Discount Model, Price Earning Ratio And Price To Book Value For Investmen Decisions. Jurnal Ilmiah Manajemen, 7(3), 276-285.

[9] Neaxie, L. V., \& Hendrawan, R. (2018). Telecommunication Company Share Valuation Using Discounted Cash Flow and Relative Valuation Method Listed in Indonesia Stock Exchange for Forecast. International Journal of Science and Research (IJSR), 7(4). https://doi.org/https://doi.org/10.21275/ART20181927 


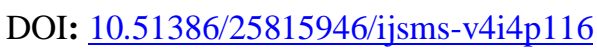

[10] Rifqiawan, R. A. (2014). Pengaruh Profitabilitas dan Kapitalisasi Pasar terhadap Nilai Emiten Jakarta Islamic Index. Economica Jurnal Penmikiran dan Penelitian Ekonomi Islam, 6(2), 21-36.

[11] Suryanto. (2016). Stock Valuation By Using Price Earning Ratio (Per) in Stock Index Lq45. AdBispreneur, 1(2), $137-144$. https://doi.org/10.24198/adbispreneur.v1i2.10236

[12] Thertina. Martha Ruth. (2020. 23 April). Krisis Bahan Baku Impor Hantui Industri Farmasi. Katadata [online]. Tersedia: https://katadata.co.id/marthathertina/Indepth/5ea13319a3dc9/krisis-bahan-baku impor-hantui-industri-farmasi. [28 Oktober 2020]

[13] Triantoro, D., \& Bertuah, E. (2020). The Determinants of Capital Structures in Automotive and Component Industries as Listed in IDX (Indonesia Stock Exchange). International Journal of Science and Management Studies (IJSMS), 3(4). https://ijsmsjournal.org/2020/volume-3\%20issue-4/ijsms-v3i4p110.pdf

[14] Utamaningsih, A. (2020). Valuation of Bumn Construction Company Stock Prices at the Time of a Bullish At the Indonesian Stock Exchange. Journal of Applied Management (JAM), 18(3), 511-521. https://doi.org/10.21776/ub.jam.2020.018.03.11

[15] Yulfita, U. (2013). Penilaian Harga Saham Sektor Manufaktur Yang Terdaftar Di Bursa Efek Indonesia (Periode 2009 - 2011). Jurnal Riset Ekonomi, Manajemen, Bisnis Dan Akuntansi (EMBA), 1(3), 1089-1099. https://doi.org/10.35794/emba.v1i3.2319 